\title{
THE IMPORTANCE OF DIALOGUE AND COOPERATION WITH THE RESIDENTS FOR URBAN DEVELOPMENT, ON THE EXAMPLE OF THE CITY OF RZESZÓW
}

\author{
Wiesława KUŹNIAR \\ University of Rzeszow, Department of Marketing and Entrepreneurship, Rzeszow; wkuzniar@ur.edu.pl, \\ ORCID: 0000-0001-8562-3511
}

Purpose: The article aims to present possible means of residents' participation in a city's development as well as to identify selected areas of such activity, on the example of the city of Rzeszów.

Methodology: The article employs critical analysis of the literature on the subject and the case study method.

Findings: Interaction between a territorial unit and its residents can, in the Author's opinion, be developed and strengthened with the use of the DART model proposed by Prahalad and $\mathrm{V}$. Ramaswama. Based on its assumptions, four basic elements of the model were adapted in the theoretical for the needs of a territorial unit: Dialogue, Access, Transparancy, Risk Assessment. Empirical verification, based on the example of Rzeszów, allows a conclusion that various forms of a dialogue with residents, transparency and timeliness of the information transfer, and the city's openness to new forms of contact with its residents fit into the assumptions of the DART model.

Practical implications: In addition to the traditional forms of utilizing the Rzeszów residents' potential, such as public consultations or participatory budgeting, Urban Lab, which has been operating in Rzeszów since 2019, is another important instrument enabling residents' participation in the city's development. Urban Lab is a modern cooperation platform available to everyone who wants to change something and set directions for the city's future development, by sharing ideas, exchanging thoughts and views. Residents can participate in the projects implemented that are addressed to various target groups, listen to experts' opinions, as well as formulate questions and express their own opinions and suggestions publicly.

Originality: Various modes in which Urban Lab can be applied as a form of residents' involvement in a city's development have been presented, which, based on the example of Gdynia and Rzeszów, should be an incentive for other cities to launch this type of initiatives enabling the use of local community's potential.

Keywords: city development, residents, participation, dialogue, cooperation.

Category of the paper: research article, case study. 


\section{Introduction}

Implementation of new public management concepts which attach increasing importance to the empowerment of citizens (Andres-Morawska, and Rudolf, 2015) is conducive to the growth of social participation. This phenomenon has been emphasized, inter alia, by B. JaworskaDębska, who pointed out that during the 30 years of local government operation, significant development of various forms of social participation took place in Poland. This has been reflected in the decision-making as well as consultative or opinion-making processes (Jaworska-Dębska, 2020).

The development of social participation fits, in particular, with the concept of Public Governance, which is characterized by greater communality in the functioning of public authorities, openness and transparency of public institutions, as well as the network-like model of the decision-making centers' functioning (Szczerski, 2005). In the concept of Public Governance, residents act as stakeholders, partners, who are not just ordinary customers, as in New Public Management, but constitute an element of the society's life, participate in the solving of collective problems, partaking in the creation of a given territory's value (Kuźniar, Kawa, 2018) .

At a city level, the participation process is reflected in the local community's increased interest in the development of its territorial unit. This translates into the residents' greater involvement in local matters, the prospects for dialogue and cooperation with the authorities, and, consequently, participation in the decisions and the activities involving urban development. One example may be the residents' co-decision-making regarding the way a specific part of public finances is spent under the so-called participatory budget, which, apart from its basic functions, also helps identify the local community's needs, supports the community's integration around the issues that are important for it (Owsiak, 2016).

Owing to the dialogue and the multi-directional communication, the residents can become a source of valuable ideas and innovative solutions, which reflect the User Driven Innovation concept (Wise, and Hogenhaven, 2008). The innovations co-created by residents are based on the use of their knowledge, creativity, experience or their willingness to cooperate.

The article aims to present possible means of residents' participation in a city's development as well as to identify selected areas of such activity, based on the example of Rzeszów. A thesis had been assumed stating that the city examined, whose motto "Rzeszów - the capital of innovation" has committed it to development of innovative solutions, should in particular manner use the residents' knowledge, creativity and involvement in the local matters, creating favorable conditions for idea and opinion sharing and exchange of suggestions for change.

The article employs critical analysis of the subject-matter literature addressing the topic undertaken. The theoretical considerations have been enriched with information obtained from the Rzeszów City Hall and the specialist reports available. As an example of how the residents' 
potential in the city examined can be used, the main concept as well as the most important areas of activity, in relation to the Urban Lab functioning in Rzeszów since 2019, have been presented as well.

\section{Dialogue and cooperation between a territorial unit and its residents, in the context of the DART model adaptation}

According to the 'Service Dominant Logic' concept, each product's value is created as a result of a co-creation process, in which the consumer plays a priority role (Vargo, and Lusch, 2004). With regard to a territorial unit, participation of stakeholder groups, especially of residents, in the process service provision, interaction occurs between local authorities and the recipients of the territorial offer, which requires not only dialogue and commitment on the part of both sides, but also mutual trust and information sharing.

Explanation and description of the interaction developed between a territorial unit and its stakeholders, which constitutes the basis of social participation, can be facilitated by the so-called DART model. Its authors (Prahalad and Ramaswamy, 2004) indicate that the interaction developed between an organization and a client in the process of value co-creation oblige both parties to respect four basic assumptions: Dialogue, Access, Transparancy, Risk Assessment.

1. Dialogue - refers not only to information exchange or knowledge sharing but should mean certain quality of the relations between the territorial unit authorities and the stakeholders. These relations should be characterized by deep commitment, ability to listen, empathy, and interactivity. Dialogue should enable the residents' involvement in the process of value for creation for a territorial unit. One example of such relations or knowledge and idea sharing may be public consultations, direct meetings of local authorities with residents, a dialogue with the local community via internet forums or social networks. They should take into account the specificity of the target groups.

2. Access - assumes the possibility using specific elements of the offer, without having to own them. As such, in order to take advantage of the offer, there is no need for ownership transfer; additionally, the local community can have access to specific services as early as at the stage of their design and project implementation, which allows "experience of the value" during the process of product development. In practice, many examples of access to public services or infrastructure can be indicated. In many cases, the local community can also participate in their design, the initial testing and modification. 
3. Transparency - i.e. transparency of the information available to the local community. This is an important aspect, since residents become increasingly involved in the development of their "small homelands", and thus have greater and greater information needs. Therefore, in order to gain the residents' trust in the local authorities, information transparency is essential (asymmetry disappears). In addition to the traditional forms of information flow, including direct messages, the newsletters issued by municipal authorities or information folders, an important information function should also be assigned to the Internet, which allows the residents to constantly follow current events, ask questions (e.g. "chatting" with the mayor), or share their ideas and observations. Social media have a particularly important role to play in this regard.

4. Risk Assessment - refers to the probability of a project's failure, or damage. Owing to the information held and the dialogue opportunities available, local community representatives can reduce the risk by taking over some responsibility for the threats associated with specific investments. The residents' role in risk assessment and reduction is to signal the threats emerging, share knowledge and experience, or propose alternative solutions. As a result, the residents take over some of the responsibility for the failures associated with the local authorities' inappropriate decisions or actions.

Respect for distinct principles creates a new quality in the relations between a territorial unit and its residents, resulting in mutual benefits, in particular:

- combination of access and transparency, which constitutes the basis for the dialogue between local authorities and residents, enabling better decision making,

- dialogue and risk assessment - facilitate joint meetings, debates, consultations (e.g. the "participatory budget" campaign), which favors joint development of specific solutions,

- transparency and risk assessment enable development of mutual trust, which facilitates creation of positive, lasting relations between local authorities and residents (Kuźniar, and Kawa, 2015).

In the process of a territorial unit's value co-creation, the so-called 'groups with high mobility potential' play an important role (Domański, 1997). Usually, it is a small group, but at the same time very creative and dynamic, playing the role of public opinion leaders and a given community's ambassadors. It should be underlined that by involving residents in the creation of the territorial offer, a new quality of the relations between a territorial unit and the main stakeholders is created, which results in mutual benefits. Joint development of specific solutions ultimately leads to the building of trust between the local authorities and the residents. This problem has been emphasized, inter alia, by I. Kowalik (2011), who pointed out that proper formation of the mutual relations between the authorities and the local stakeholders, especially the residents, allows development of strategic competitive advantage, which contributes to the unit's so-called relational capital. 


\section{Possible means of the Rzeszów residents' participation in the city's development - selected practical examples}

The investments implemented in Rzeszów in many cases result from the cooperation between the city authorities and the local community representatives, including residents. The impact the residents have on the city's development has been possible owing to the various forms of participation, the most important of which are participatory budgeting, public consultations, or numerous, direct meetings of the mayor with the local community.

In the last few years, the Rzeszów Participatory Budget has been an instrument allowing the residents to co-decide on partial spending of the city budget. This has enabled the residents to be engaged in the process of city management by co-decision-making regarding the way a strictly defined part of the budget, the value of which has been systematically increasing over the last of 7 years (Table 1), reaching 10 million in 2020. PLN, is spent (Bulletin of Public Information, 2020).

Table 1.

Primary data characterizing participatory budgeting in Rzeszów

\begin{tabular}{|l|c|c|c|c|c|c|c|}
\hline \multirow{2}{*}{ Item } & \multicolumn{7}{c|}{ Year } \\
\cline { 2 - 9 } & $\mathbf{2 0 1 4}$ & $\mathbf{2 0 1 5}$ & $\mathbf{2 0 1 6}$ & $\mathbf{2 0 1 7}$ & $\mathbf{2 0 1 8}$ & $\mathbf{2 0 1 9}$ & $\mathbf{2 0 2 0}$ \\
\hline Amount in million PLN & 5.0 & 6.5 & 7.5 & 7.65 & 7.65 & 7.65 & 10.0 \\
\hline Number of voters (in thousands) & 34.5 & 21.7 & 22.6 & 36.7 & 15.1 & 19.7 & 25.0 \\
\hline Voter turnout (in \%) & 23 & 14 & 15 & 23 & 8 & 10 & 17 \\
\hline
\end{tabular}

Source: own elaboration based on the Rzeszów City Hall data.

When analyzing the data in Table 1, it can be noticed that the greatest involvement of the Rzeszów residents in the development of the participatory budget had been recorded in the first year of its operation. In the following years, varied interest was noticeable, whereas the lowest share of residents in the voting was recorded in 2018, when the very low (8\%) turnout was explained by poor transfer of information. In subsequent years, owing to the activation of the local community, interest in the participatory budget began to grow again. It is worth noting that each year the share of the votes cast via the Internet was increasing, which allows a prediction that in the upcoming years the turnout will systematically increase, especially among younger residents.

When submitting project proposals, the residents of Rzeszów can choose from three categories of activity (Table 2):

I - construction, modernization or renovation of the city infrastructure.

II - construction, modernization or renovation of housing estate infrastructure.

III - pro-social, cultural, educational or sport-related activity. 
Table 2.

Number of projects financed as part of the Rzeszów ParticipatoryBbudget

\begin{tabular}{|c|c|c|c|c|c|c|c|}
\hline \multirow[t]{2}{*}{ Item } & \multicolumn{7}{|c|}{ Year } \\
\hline & 2014 & 2015 & 2016 & 2017 & 2018 & 2019 & 2020 \\
\hline Category I & \multirow{3}{*}{$10 *$} & 1 & 6 & 4 & 6 & 5 & 5 \\
\hline Category II & & 5 & 17 & 21 & 18 & 18 & 21 \\
\hline Category II & & None** & 9 & 9 & 12 & 7 & 21 \\
\hline
\end{tabular}

*in 2014 no category was distinguished.

**in 2015 categories I and II were distinguished.

Source: own elaboration based on the Rzeszów City Hall data.

The projects earmarked for participatory budget financing primarily fall within the categories associated with housing estate infrastructure modernization and general-public activities (especially of a sport-related nature). Based on the results of a research conducted by M. Kowalska-Chrzanowska in 18 voivodship cities, participatory budgeting cannot be considered an effective tool reinforcing active participation of citizens in cultural life (Kowalska-Chrzanowska, 2019). In relation to Rzeszów, this regularity has been only partially confirmed.

The first year of participatory budgeting, particularly the residents' high voter turnout, inspired the city of Rzeszów authorities to launch a social platform (dobrepomysly.erzeszow.pl). It is meant to enable the residents to submit, all year long, ideas and specific solutions aimed at improvement of the quality of all spheres of urban life. It is worth noting that the proposals submitted not only concerned investment activity, but also contained ideas for public and charity campaigns as well as cultural, sporting or entertainment events. What is more, each logged in portal user can comment on the proposals submitted, which allows ongoing verification of the usability and the attractiveness of the ideas propounded. This is important information for the city authorities, affecting the decisionmaking regarding the projects undertaken. It is based on the principles of crowdsourcing, the overarching idea of which is to 'draw on the wisdom of the society'.

The Rzeszów residents' involvement in the development of the city is favored by an extensive system of marketing communication via various media. Unusual forms of promoting the city's assets and the current problems associated with its development include the messages posted on LCD monitors on public transport buses, which display city advertisement spots, information regarding upcoming events and all kinds of awards received by the local government, or other information pertaining to municipal matters. Similar information can be obtained through free text messages. Residents can also subscribe to the newsletter, in order to receive city news via e-mail. Additionally, social networks (Facebook, YouTube, Instagram, Google+, Pinterest, Twitter), which enable interaction with the residents, play an important information function as well. It should be emphasized that the city of Rzeszów is open to dialogue with various target groups, while its profile moderators are very active, trying to respond to the user comments. The two-way and multi-directional information 
flow fosters the growth of trust and highlights the city's openness to new forms of contact with residents, which is in line with the assumptions of the DART model.

The Rzeszów residents' sense of satisfaction with the quality of life in the city and the directions of its development have been confirmed by city's high positions in national and international rankings, including its fifth position in the Quality of Life Ranking (Index, 2018). It is worth underlining that in the "Community" category, reflecting civic involvement, Rzeszów was ranked quite high, i.e. third. This category includes selected aspects of the residents' activity in political and social life, e.g. participation in local government elections or involvement of municipal movements in environmental protection, including the fight against smog. In reassumption, Rzeszów obtained $94.46 \%$, which allows for a high assessment in terms of the direction of the socio-economic changes that have taken place in Rzeszów in recent years.

\section{Urban Lab as a form of using the city residents' potential}

Urban Lab is a project jointly developed by the Ministry of Investment and Economic Development and the Institute of Urban and Regional Development, entitled "Urban Lab as a pilot tool to improve the quality of the residents' life in accordance with the smart city idea (original in PL: Urban Lab, jako pilotażowe narzędzie poprawy jakości życia mieszkańców miast zgodnie z ideą smart city)". It was introduced in 2019 as a pilot project in two cities: Gdynia and Rzeszów. PLN 3.5 million has been allocated for the project implementation in Rzeszów, PLN 2.6 million of which is EU funding.

The essence of the project entails the city's cooperation with enterprises, scientific entities, non-governmental organizations and the residents. This cooperation, based on a diagnosis of specific stakeholder groups' problems and needs, aims to improve the quality of urban life and functioning. The Urban Lab activity, being a cooperation platform available to all who want to change something and set directions for the city's future development by sharing their ideas and exchanging thoughts and views, results in the implementation of innovative solutions and improvements. Another important objective associated with the project activity is to support potential entrepreneurs, mainly through professional consultancy in relation to startup development.

There are four most important functional areas constituting the pillars of Urban Lab (BIP, Dobre Praktyki, 2020):

1. Institutions searching for partners who would seek solutions to the urban problems diagnosed and possible pilot implementations of the solutions developed for selected problems. 
2. Institutions rendering the city's resources (including data sets) accessible to the entrepreneurs, individuals and NGOs striving to develop new methods of using these resources for improvement of the residents' quality of life.

3. Urban Cafes - places of inspiration, forums for exchange of modern urban thought, inviting experts from Poland and abroad, organizing events, seminars, trainings, summer schools, etc.

4. Innovation incubators - institutions offering support in the incubation process of innovative ideas that are focused on solving urban problems (including, e.g., support for technological projects, but also for social innovations addressed to the people who are at the highest risk of social exclusion), searching for financial sources as well as funding the grants aimed at 'first business' development.

In less than a year of the functioning of Urban Lab in Rzeszów, many substantive meetings, conferences and creative discussions took place as part of the activities carried out. Part of the expert group discussions constituted an introduction to city-wide consultations, an example of which can be the newly-developed "Study of the Conditions and Directions for Spatial Development in Rzeszów (original in PL: Studium Uwarunkowań i Kierunków Zagospodarowania Przestrzennego Rzeszowa)". The online broadcasts via the Facebook profile of the Urban Lab Rzeszów allow the residents not only to follow the discussion on an ongoing basis, but also to formulate questions or express their opinions and post suggestions on the forum.

The issues raised within the Urban Lab target various stakeholder groups and address many areas of social life. One example is the "City for people who are lifelong active" (original in PL: Miasto dla aktywnych przez całe życie ) project - undertaking the taks of ensuring optimal living conditions for all residents, with particular emphasis on active aging. This means the strive to ensure the longest possible independence of the city's inhabitants in everyday functioning and to enable active participation of seniors in social and economic life. Improvement of the quality of older people's lives entails, at the same time, acting for the benefit of all social groups and support of the city's development, in accordance with the concept of silver economy.

Many specialist projects, including the "Robot Challenge - mobility in a city of the future" (original in PL: Robot Challenge - mobilność w mieście przyszłości), have also been consulted with experts at the Urban Lab headquarters. As part of the project, the KIDS HACKATHON was organized, during which children were developing solutions that would, from their perspective - i.e. reaching Mars, be most beneficial for the city. The project's main objective was to promote robotics, science and modern technologies as opportunities offering better future for young students. The project targeted primary school youth and their teachers.

Another important element of Urban Lab activity is the thematic conferences, for instance, the "Eco-mobility and alternative forms of transport" (original in PL: Ekomobilność i alternatywne formy transport) conference, during which three thematic blocks that are 
important for the city's perspective were discussed: infrastructure for alternative forms of transport, optimal use of 'clean energy' - energy storage and autonomous buses - as a symptom of public transport development.

The so-called 'business breakfasts', aiming to build a more effective innovation market, have been the flagship of the Urban Lab project. They are attended by representatives of corporations, large companies, startups, as well as the scientific communities and public institutions. One important subject discussed is the proposals of startup solutions, which often are ahead of the initiatives improving the quality of life.

The above-presented examples constitute only a part of the initiatives implemented and the projects coordinated by the Urban Lab. The most important objective, and at the same time a challenge, entails an attempt to implement real changes in the urban space, developed as a result of the cooperation between various groups of stakeholders, as well as to make Rzeszów a modern city capable of supporting various forms of innovation.

\section{Conclusions}

The residents' activity within the local-government community, has been primarily related to the grassroots initiatives on their part, which is reflected in the local community's participation in territorial unit management. This can be manifested on many dimensions, especially via the opinions and assessments expressed, the suggestions for changes proposed, or the specific activities associated with various initiatives aimed at development of a given unit. The use of the residents' and other stakeholders' potential requires the local authorities to pursue a policy that facilitates co-creation of a given territory's value by, inter alia, the strengthening of the relations with residents, based on mutual trust (dialogue) and reliable information transfer regarding the decisions made or the activities undertaken (transparency).

These assumptions should be reflected in the practical functioning of territorial units, especially the cities predisposing to the name of important innovation centers, because the 'drawing on the wisdom of the society' may constitute an important impulse in the implementation of the innovative solutions improving the city's functioning and its residents' quality of life.

Openness to the forms of contact with residents, based on modern technologies enabling multidirectional dialogue in a hypermedia environment, plays an important role when it comes to development of conditions for residents' participation in the life of the city, as exemplified by the Urban Lab concept. This, however, does not diminish the role of traditional direct meetings of the city authorities with residents as part of public consultations. The concept of participatory budgeting is also an important instrument enabling the residents to participate in the city's development in recent years. It should be noted, however, that many critical voices 
appear regarding this form of participation, indicating that due to the limited financial resources, such participation is only apparent. According to the Author, the activities undertaken as part of participatory budgeting are of great advantage and favor this form of participation, because it is important to make the residents aware of the fact that they can have influence on the city's development and are, which in turn motivates them to act for their future common benefit.

\section{References}

1. Andres-Morawska, J., and Rudolf, W. (2015). Orientacja rynkowa we wspótrzadzeniu miastem. Łódź: Uniwersytet Łódzki Publishing.

2. Biuletyn Informacji Publicznej Miasta Rzeszowa. Dobre praktyki. Urban Lab. https://bip.erzeszow.pl/print/100/4240/4870, 03.08.2020.

3. Biuletyn Informacji Publicznej Miasta Rzeszowa. Rzeszowski Budżet Obywatelski. http://s.bip.erzeszow.pl/konsultacje-spoleczne/rzeszowski-budzet-obywatelski, 07.08.2020.

4. Domański, T. (1997). Marketing terytorialny - wybrane aspekty praktyczne. In: T. Domański (Ed.), Marketing terytorialny. Strategiczne wyzwania dla miast i regionów. Łódź: Centrum Badań i Studiów Francuskich, Instytut Studiów Międzynarodowych, 22-23.

5. Jaworska-Dębska, B. (2020). Partycypacja społeczna w samorządzie terytorialnym. Przemiany koncepcji prawnej i praktyki w latach 1990-2020. Zagadnienia wybrane. Samorzad Terytorialny, 3, 49-64.

6. Kowalik, I. (2011). Orientacja rynkowa $w$ polskim samorzadzie lokalnym. Warszawa: Oficyna Wydawnicza SGH.

7. Kowalska-Chrzanowska, M. (2019). Budżet obywatelski jako instrument partycypacji społecznej w obszarze kultury. Zarzadzanie w Kulturze, 20, 1, 57-77.

8. Kuźniar W., and Kawa, M. (2015). Relacje jednostek samorządu terytorialnego z mieszkańcami w kontekście koncepcji współtworzenia wartości. Marketing i Zarzadzanie, 40, 279-287.

9. Kuźniar, W., and Kawa, M. (2018). Komunikacja marketingowa w jednostkach terytorialnych - od jednokierunkowego oddziaływania do interaktywnego dialogu. Handel Wewnętrzny, 4(375.) Vol. II, 49-59.

10. Owsiak, K. (2016). Wykorzystanie wybranych narzędzi public governance przez jednostki samorządu terytorialnego w Polsce a wzrost partycypacji społecznej. Studia Ekonomiczne, 294, 109-120.

11. Prahalad, C.K., Ramaswamy, V. (2004). The Future of Competition. Co-Creating Unique Value with Customers. Boston: Harvard Business School Press. 
12. Ranking Jakości Życia, https://www.miasta.pl/uploads/attachment/file/2367/RANKING_ MIAST-Polityka.pdf, 07.08. 2020.

13. Szczerski, K. (2005). Administracja publiczna w modelu zarzadzania wielopasmowego: wyzwania dla rozszerzonej Unii Europejskiej - przypadek Polski. Warsaw: Natolin European Centre.

14. Vargo, S.L., and Lusch, R.F. (2004). Evolving to a New Dominant Logic for Marketing. Journal of Marketing, 68, 1, 1-17.

15. Wise, E., and Hogenhaven, C. (2008). User-Driven Innovation. Context and Cases in the Nordic Region. Oslo: Nordic Innovation Centre. 